\title{
Estudos camonianos
}

\section{SEGISMUNDO SPINA}

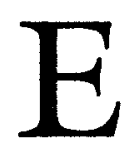

m 1963, com a criação da disciplina de Camonologia nos cursos de Letras da Faculdade de Filosofia, Ciências e Letras da USP, surgiu a idéia de justificar a sua presença com a publicação de uma revista dedicada aos estudos em torno do grande poeta português do Renascimento. A primeira Cadeira de Estudos Camonianos havia sido criada na Faculdade de Letras de Lisboa, em 1924, por sugestão do grande camonista brasileiro, Afrânio Peixoto, e cujo primeiro titular, José Maria Rodrigues, assumiu a sua regência até 1933, quando Hernâni Cidade o sucedeu. Criada a exemplo do que ocorria com a Cadeira de Dante, em Florença, desde o século XIV, uma década depois a $\mathrm{Ca}$ deira deixava de existir.

Em 1963 o Instituto de Estudos Portugueses da USP, com o patrocínio inicial da Casa de Portugual de São Paulo, pode ver concretizada a realização de uma revista especializada na disciplina de Camonologia.

Para desconcerto dos pessimistas, de cá e de além mar, a Revista Camoniana foi cumprindo, em meio a inúmeras dificuldades, o programa que inicialmente se propôs, de articular os estudiosos e especialistas no campo da Camonologia, dispersos como estavam pelo mundo das letras e publicando as suas pesquisas e seus estudos, muitas vezes, em revistas completamente estranhas à esfera literária. Com isso, conseguimos formar uma família de abnegados da crítica e da erudição camonianas, exegetas e afeiçoados. Assim, fomos também ressarcindo uma dívida para com o Príncipe dos Poetas líricos e heróicos da Península. A revista, sob a direção de seu criador, professor Segismundo Spina, realizou os três primeiros números, até 1971, quando a sua direção e a sua nova série ficou sob a responsabilidade da professora Maria Helena Ribeiro da Cunha, que mantém viva a publicação até o número 8, com o seguinte no prelo. A aquilatar-se do alto padrão de qualidade dos trabalhos publicados, é só compulsar os índices de seus onze números.

A disciplina de Camonologia passou, desde a sua criação, a responder pelos cursos de Pós-Graduação na área camoniana, na qual realizou inúmeras dissertaçōes de mestrado e teses de doutoramento, afora vários ciclos de conferências e cursos de extensão universitária pelo interior do estado, na Casa de Portugual, na Tribuna de Santos e no pró- 
prio auditório do então Instituto de Estudos Portugueses. A tese de livre-docência da nova diretora da revista também versou matéria camoniana, publica em 1989 pela Imprensa Nacional - Casa da Moeda de Lisboa, sob o título de $A$ dialética do desejo em Camóes. Em 1981, Gersey Georgette Yahn havia obtido o $1^{\circ}$ Prêmio no Concurso de Monografias promovido pelo Real Gabinete Português de Leitura do Rio de Janeiro, por ocasião do IV Centenário da morte de Luís de Camóes, trabalho publicado por aquela instituiçáo sob o título de $O$ bomem sob o signo do desterro: uma elegia de Camốes.

Em 1987, a disciplina de Camonologia pode ver coroada a sua trajetória com a realização, na Faculdade de Filosofia, Letras e Ciências Humanas da USP, da V Reuniáo Internacional de Camonistas, que congregou nada menos de $\mathbf{7 5}$ participantes, especialistas de várias procedências universitárias (Brasil, Portugal, França, Alemanha, Inglaterra, Açores, Itália e Estados Unidos), cujas Actas publicadas pela Universidade de São Paulo atestam o alto nível das 54 Comunicações apresentadas.

Segismundo Spina é professor emérito da Faculdade de Filosofia, Letras e Ciências Humanas da USP. 